\title{
THE PILEGESH: STATUS OR TOPOS?
}

The term pilegesh, found in biblical and postbiblical Hebrew פלגש/פילגש, is generally taken as the equivalent of the English word "concubine". ${ }^{1}$ Yet the idea of concubinage itself (like the idea of slavery) is quite vague, ${ }^{2}$ and this lack of precision is exacerbated in the attempt to compare concubinage terms in different languages and periods. ${ }^{3}$

Further, it is often assumed that concubinage was in some way connected with female slaves. As Ellinson notes, for instance, postbiblical sources often assumed that the pilegesh was a shif̣ab who had been sexually coerced by her master; ${ }^{4}$ certain modern scholars also propose that a concubine would have started out as a slave, or that concubinage was in fact the inevitable disposition of all female slaves. ${ }^{5}$

In fact, the term appears sporadically in the Bible, in some instances associated with named individuals. ${ }^{6}$ In the Pentateuch the term appears

1 This is so even in the earliest translations: we find such terms as לחנתא and לחנ in the

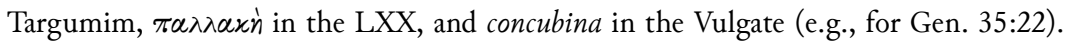

2 "Concubine" is generally not used as a precise legal term in English, but can describe a variety of relationships, both temporary and permanent, monogamous or otherwise. On a social level, "concubine” may connote semi-respectability or licentiousness, depending on perspective.

3 I shall argue in chap. 7 that לחנתא, like its apparent Akkadian cognate labbi/anatu, suggests a subordinate rather than a concubine.

4 Elyaqim Ellinson, Nissuin Not in Accordance with the Law of Moses and Israel [in Hebrew] (Tel Aviv: Dvir, 1975), 53. Ellison cites as one notable example the מעשה בוסתנאי in the Iggeret Rav Sherirab Gaon, in which an antecedent of a particular gaonic dynasty was accused of having married his slave woman.

5 See, e.g., B. Cohen, Jewish and Roman Law, 329; Patai, Sex and Family, 42; and Flesher, Oxen, Women or Citizens? 17 n. 17. This opinion will be discussed more fully below.

6 The named pilagshim are: Re'umah, the pilegesh of Nahor (Gen. 22: 24); Bilhah, the slave-wife of Jacob (Gen. 35:22); Timnah, the pilegesh of Elifaz (Gen. 36:12); Ritzpah, the pilegesh of Saul (2Sam. 3:7 and 21:11); Qeturah, the pilegesh of Abraham (1Chr. 1:32, 
only in the foundation narratives in Genesis and not in any of the legal portions. The term has only one direct association with slaves, and we may thus deem this association incidental: Bilhah, the slave-wife of Jacob, is termed a pilegesh in Gen. 35:22. ${ }^{7}$ Unlike the terms shifbah and amab, the term pilegesh is never associated with the male slave term eved. If it appears in lists at all, it is associated with wives (for instance, those of David in 2Sam. 5:13; of Solomon in 1Kings 11:3; and of the court in Cant. 6:8). The bizarre story of the pilegesh of Givah in Judges 19-21 uses kinship terminology otherwise associated with a marital-type situation: the woman is referred to as an ishab pilegesh $(19: 1,28)$, the Levite as ishab ("her husband"; 19:3), and her father as the Levite's boten ("father-in-law"; 19:4). ${ }^{8}$ Further, Qeturah is described in Gen. 25:1 as the ishab of Abraham, while in 1Chr. 1:32 she is described as his pilegesh. ${ }^{9}$

Most significant, in my opinion, is that certain pilagshim are very noticeably associated with sexual assaults: the assault on Bilhah by Reuven (Gen. 35:22); the rape and dismemberment of the pilegesh of Givah (Judg. 19-2 $1^{10}$ ); the alleged assault on Saul's pilegesh by Avner (2Sam. 3:7); the assault on David's pilagshim by his son Avshalom (2Sam. 16:21-2). There is the further curious point that the pilagshim in Ezek. 23:20, also associated with profligate sexual behavior, appear to be males.

The term all but disappears in the pre-gaonic legal canon, with two exceptions that will be discussed below. It does appear sporadically in

though in Gen. 25:1 she is called his ishab); Eifah and Ma'akhah, the pilagshim of Caleb (1Chr. 2:46, 48). There is only one direct instance in which pilagshim are associated in any way with slave terminology: Bilhah is called a pilegesh only in Gen. 35:22 and is otherwise described as an amah, shifbah, or ishah. There is also an indirect association: Avimelekh, who is stated to be the son of Gideon's (unnamed) pilegesh, is in one instance called a ben amab (Judg. 9:18). The significance of these instances is discussed further in this chapter.

7 As mentioned above, there is one indirect association in Judg. 9:18, in which Avimelekh is called a ben amah.

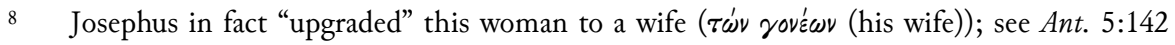
(trans. H. St. J. Thackeray; 9 vols.; London: Heinemann, 1926-1965).

9 A midrash associated with Rav (Gen. Rab. 61:4 and elsewhere) identifies Qeturah as Hagar.

10 As noted in Harris, R. L. et al., eds., Theological Wordbook of the Old Testament [=TWOT] (2 vols.; Chicago: Moody, 1981) s.v. "concubine," one-third of the biblical occurrences of pilegesh are in this Judges narrative. 
aggadic material, but apparently describes a (female) consort of low social status, rather than a specific legal status, ${ }^{11}$ as can be seen in the following midrash in Lev. Rabbah parsha 1:13:

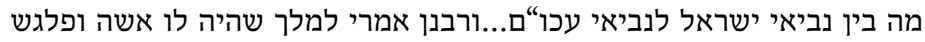

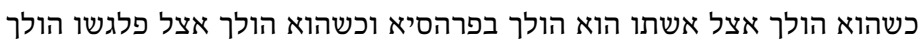

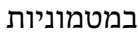

What is the difference between the prophets of Israel and the prophets of the other nations?... The Sages say: [it is like] a king who had an ishab and a pilegesh [in some versions a shifbab]; when he goes out with his wife he does so in public view, but when he goes out with his pilegesh he does so discreetly.

Undoubtedly, the pilegesh was associated with sexual behavior, and undoubtedly a sexual use was one of the functions of a female slave, though not an inevitable function. Even if we describe this as "concubinage," however, I do not think the term "concubine" should be used as the translation for pilegesh. I will argue that a better translation is "consort," to avoid the sole association with females that is implicit in the modern term "concubine" and thus include the male pilagshim in Ezek. 23:20. Further, I argue that pilegesh is used in the Bible as part of a literary motif rather than as an indication of a particular status, and that there is no necessary association of the pilegesh with slavery. The pilegesh is outside the family; his or her sexuality is not licit in the normative sense and leads to disinheritance or death. It is the pilegesh, not the slave, who is the true "other."12

\subsection{ON THE WIFE-SLAVE CONTINUUM?}

As noted above, there is concern evidenced by both ancient and modern scholars to rank biblical females in comparison to a "legitimate" wife. ${ }^{13}$ For

11 Several of these are discussed by Ellison, Nissuin, 47-49.

12 The pilegesh may have had some legal advantages in later periods as a contract can allow a mutual exit strategy. What became normative in later rabbinic law was the unilateral acquisition of the woman by the man accompanied by her inability to initiate divorce. [TM]

13 Modern Israeli law continues to use the term pilegesh with the specific legal meaning 
the pilegesh, this is seen already in two apparently contradictory passages in the two Talmudim, which suggest a sort of unprotected wife. The first text is $y$ Ketub. $5: 229 \mathrm{~d}$ :

אי זו היא אשה ואי זו היא פילגש

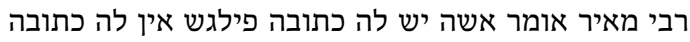

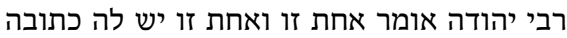
אשה יש לה כתובה ותנאי כתובה פילגש יש לה כתובר זהת זובה ישובה ואין לה תנאי כתובה

What is a wife and what is a pilegesh? R. Meir says: a wife has a ketubbab [marriage contract], and a pilegesh does not have a ketubbah.

R. Yehudah says: each one has a ketubbab; a wife has [both] a [written] ketubbab and [negotiated] conditions, and a pilegesh has a [written] ketubbab and no [negotiated] conditions.

The second text is bSan. 21a:

מאי נשים ומאי פילגשים אמר רב יהודה אמר רב נשים בכתובה ובקדושין פלגשים פשים בלא כתובה ובלא קדושין

What are wives and what are pilagshim? Rav Yehudah said in the name of Rav: wives have a ketubbab and qiddushin; pilagshim have neither a ketubbab nor qiddushin.

The Yerushalmi has been interpreted to mean ${ }^{14}$ that the pilegesh, like the wife, has qiddushin, though possibly not a ketubbah, contrary to the

of "reputed wife" (A. L. Grivsky, "Concubinage in Israel" [in Hebrew] [Molad, 1959], 666-70), a woman in a long-term relationship who has not undergone the formalities of marriage. Such a woman may benefit from certain legal rights accorded to wives in "formal" marriages, such as pension rights (Pinhas Shifman, "Marriage and Cohabitation in Israeli Law," Israel Law Review 16 [1981]: 456). Socially, however, she may be considered inferior (Daniel Friedmann, “The Unmarried Wife in Israeli Law," Israel Yearbook on Human Rights 2 [1972]: 298).

14 Rashi to Gen. 25:6, for instance, has נשים בכתובה פלגשים בלא כתובה (wives have a ketubbah, pilagshim do not have a ketubbab); this is taken as an indication that he understood the distinction between them to relate only to the ketubbab and thus assumed that both had qiddushin (see, e.g., Ellinson, Nissuin, 3). 
development by arguing that the pilegesh was a woman in an incipient $b a^{\prime} a l$ marriage - that is, unlike the woman in the beena marriage, who stayed with her father's group, the pilegesh, likely acquired as a war captive or by an exchange of some kind, remained with the husband. Morgenstern argued that this type of incipient $b a^{\prime} a l$ marriage likely always existed alongside the beena marriage type, until it gradually became the prevailing mode. $\mathrm{He}$ supports this proposition by noting, first, that the likelihood that pilegesh is a non-Semitic word may indicate that it was originally applied to foreign captives, and second, that this meaning (a foreign wife who stays with the husband) would fit the biblical instances of this term recording "ancient" traditions - the Genesis texts and Judges $19 .{ }^{20}$ After $b a$ 'al marriage became prevalent, the term pilegesh, in Morgenstern's opinion, "could acquire only one meaning, 'concubine,' since from the first it designated a wife of an inferior type and standing." 21

One may, however, argue against these (generally non-contextual) studies, particularly that of Morgenstern, that they are circular, starting with the premise that pilegesh must refer to a female and must refer to a type of relationship inferior to marriage. ${ }^{22}$

A second view places the pilegesh closer to the female slave and makes the specific assumption that a pilegesh would have started out as a slave in her master's household. We have noted Ellinson's observation that a blurring of the distinction between the pilegesh and the slave woman is already noticeable among early commentators, as can be seen in the following statement by the 12 th century sage Avraham ben David (Rabad): ${ }^{23}$

Morgenstern, “Beena Marriage," 57-58, notes that Avimelekh's mother is called a pilegesh in Judg. 8:31, though this seems to be a beena marriage with Gideon. He explains this exception in a somewhat farfetched way, by arguing that she could not be called an ishab, since this referred to a woman in a ba'al marriage; but the readers of this text, though it belongs to an "older" tradition, would not have understood amab and shifbab in their original connections to beena marriage. This seems unlikely, if for no other reason that Avimelekh is actually called a ben amah in Judg. 9:18.

21 Morgenstern, “Beena Marriage," 58.

22 Further cautions with respect to Morgenstern's argument were noted earlier in this chapter.

23 Ellinson, Nissuin, 54. We may note the similar opinion of Nahmanides on Lev. 19:20:

עמה תקרא הכתוב שהיא שפחה נערה לאיש ידוע כי הפלגש אשר היא משרת את האיש וישכב יאביו... 
הפילעלי הלשון דורשין פילגש....... שגל. לפעמים למשים למשגל ולשמש את הבית. הפילגש נחשבה למעשה לשפחה המשמשת את בעלה...לעתים לתענוגות ולמשים ולעתים

למלאכות.

[Rabad states:] 'The language experts explain pilegesh ... as pi shagel [ shagel = intercourse], ${ }^{24}$ at times to service and to serve the household.' The pilegesh...is [thus] perceived as a shif̧̣ab who services her master...sometimes for pleasure and sometimes for labor.

More recent opinion also sees the pilegesh as a wife who is "tainted" in some way by slavery; this interaction of "slavery" with "wifehood," however, is not understood consistently. Ariel, basing himself on the traditional etymology of pilegesh as פלג אשה, "half wife," argues that such a woman was more than likely to have started life as a slave, given that a free woman would never have agreed to such a presumably reduced status, while a slave may have seen it as a step up, or was in any event coerced into such a relationship. ${ }^{25}$ Patai suggests that such a woman would have retained her slave status and this is what would distinguish her from a "wife." ${ }^{26}$ Neufeld saw no philological difference between amah, shifhah, and pilegesh, though he argued that the pilegesh may have been associated with a greater laxity of morals (based, for instance, on the Bilhah-Reuven incident of Gen. 35:22, to be discussed further below), and was possibly more akin to a prostitute. ${ }^{27}$ McComisky also treated the three terms as synonymous, but seems to have considered them all equivalent to "concubine," which he took to be in essence a "secondary wife." ${ }^{28}$ Epstein, in contrast, designates concubinage

Scripture is saying that she is a shifhab girl for a certain man. It is known that the pilegesh who serves a man and with whom he lies is called his 'girl' (na'arab)...

24 We may also note the association in the LXX of Aramiac שגלתה of Dan. 5:2, 3, 23 with

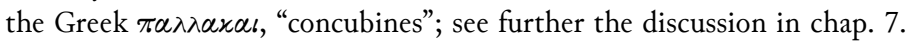

25 Yaqov Ariel, "The Pilegesh and her Halakhic Status in the Bible," Megadim 8 (1989): 5859. The essence of pilagshut that differentiated it from "wifehood" was, in Ariel's opinion, that it started as a real qinyan (purchase); with wifehood, in contrast, the term ba'al signified not a monetary transaction but a legal relationship with superficial resemblances to a qinyan.

26 Patai, Sex and Family, 41-42.

27 E. Neufeld, Ancient Hebrew Marriage Laws (London: Longmans, Green, 1944), 121, 123.

28 Thomas McComiskey, "The Status of the Secondary Wife: Its Development in Ancient Near Eastern Law, A Study and Comprehensive Index” (Ph.D. dissertation, Brandeis 
as a specific legal status higher than that of the "slave-wife." The biblical pilegesh reflects what he calls the "oriental" type of concubinage; she is part of a patriarchal, extended family structure in which the concubine is in essence a wife, with the same legal strictures regarding inheritance, adultery, and incest, but of lower rank than the chief wife. This type of extended family structure might also have included the freedwoman, captive wife, slave wife, and female slave, with associated legal statuses of descending rank, though not necessarily with discrete boundaries between these categories. ${ }^{29}$ This type of concubinage, in his opinion, disappeared as family structure changed, with the rise of non-agriculture based economies and the increased centrality of the individual; he argues that the later sages were unfamiliar with the "oriental" (corporate) style of concubinage and that their understanding of pilegesh reflects the "occidental" type of concubinage. ${ }^{30}$

There are difficulties with each of these arguments. The biblical evidence explicitly associates pilegesh with a slave in only one instance, so that one must question both the necessity of associating the term with slavery and its synonymy with amab and shif̣ah. Epstein's argument, on the other hand, seems to assume more of a legal distinction than is supported by the biblical text. While it is possible, or perhaps inevitable, that there were ranks of women within a complex household, this cannot be supported simply by assuming, first, that pilegesh means "female concubine," and second, that all women were to be legally ranked according to a single concept of "marriage." In summary, I do not think that there is compelling evidence to place the pilegesh anywhere on a wife-slave continuum.

\subsection{FOREIGN LOANWORD?}

Following on the idea that the pilegesh is not part of any status hierarchy, the most interesting scholarly opinion is etymological: the term may be a foreign loanword.

University, 1965), 1, 91.

29 Epstein, “The Institution of Concubinage," 154, 156. Raymond Westbrook, Old Babylonian Marriage Law (Horn: Ferdinand Berger, 1988), 111, also argues that there was a distinction between a "slave-wife" and a "slave-concubine" in Old Babylonian law.

30 Epstein, “The Institution of Concubinage" 156, 159. 
There are traditions deriving pilegesh from a combination of Hebrew words, such as palag, peleg, and ishah, in effect meaning "half-wife" (Mandelkern, s.v. פלגש), or pilug and sbimush, with the implication of a woman "used" by different men (Midrash Sekbel Tov to Gen. 35:22). As will be discussed in chapter 7 , there is in fact evidence of half statuses in mishnaic and later law. Other scholars, however, suggest that these derivations are folk etymologies ${ }^{31}$ and question whether the term is Hebrew, or even Semitic, in origin. A computer search of the biblical text

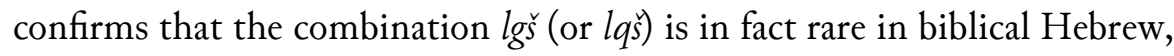
the only other instance being the description of the prophet Nahum as האלקשי (Nahum 1:1). A further point against a Hebrew origin, suggested by Rabin, is the absence in biblical Hebrew of a noun with a similar pattern ${ }^{32}$ (although we may note that there are proper nouns that seem to have the same form, particularly תלשת and תגלת B. Rabin's view, arguing against a Semitic origin in general, is the lack of any phonetic-semantic parallels in other Semitic languages. ${ }^{34}$ This suggests the possibility of a loanword, and the consequent speculation as to why the term was borrowed.

Scholars have proposed various other languages of origin, including

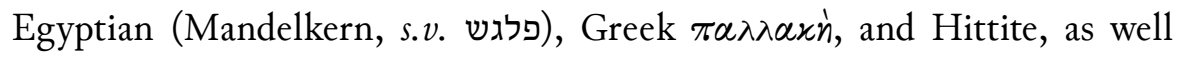
as the reverse possibility that the term entered Greek and Latin as a Phoenicio-Semitic loanword. ${ }^{35}$ Rabin's own proposal ${ }^{36}$ is that the term is composed of two Indo-European elements: the prefix pi-, "at, on, towards," and the root legh-, "to lie down," plus a suffix. The term is taken to mean "by-lier," a concept that Rabin notes is expressed in other

31 Regarding the former derivation, at least, this is the opinion of Even-Shoshan (s.v. פלגש .

32 C. Rabin, “The Origin of the Hebrew Word Pilegeš,” JJS 25 (1974): 356.

33 The latter represents the biblical version of the Akkadian (Tukultī) apil-ešarra. This suggests a possibility, which I shall not explore further here, that pilegesh is derived from an Akkadian compound that includes the term apil, "heir of." The association with a male figure would certainly fit with the idea of male pilagshim in Ezekiel.

34 Rabin, “Origin," 356-57.

35 See, e.g., McComiskey, "Secondary Wife," 91 (Greek); John Pairman Brown, Israel and Hellas (ZAW Supp. 231; Berlin: De Gruyter, 1995), 70 (Hittite); Epstein, “Concubinage," 153 (Phoenicio-Semitic). A summary of earlier speculations on the origin of pilegesh is found in Rabin, "Origin," 353 nn. 2-6.

36 Rabin, “Origin,” 358. 
Indo-European languages, though with different terms. He suggests that the most likely Indo-European contact with Hebrew in this case would have been through the Philistines, though of course he can cite no extant parallels. While he acknowledges the difficulty posed by selecting linguistic elements from the "unlimited possibilities of the phonology of an unknown language," he supports his contention by noting that many of the biblical references to pilagshim in the Israelite period have to do with men from Judah and Benjamin, two areas in close contact with the Philistines. ${ }^{37}$

Levin supports this contention, adding a possible motive for the borrowing of this word: the prefix (e)pi suggests a non-endogamous woman, and the Philistines (=Pelasgians in Greek tradition) had a reputation (as attested in Herodotus) for "craving foreign women." ${ }^{38}$ The attraction of this practice, particularly for men such as the Levite of Judges 19-20 who did not have a stable residence and might thus find it difficult to attract a wife, led to this type of "intermarriage" being incorporated within other cultures in contact with the Philistines, though subject to much censure. ${ }^{39}$

Again, there is the difficulty with the arguments of Rabin and Levin that they start with the assumption that pilegesh refers to a female concubine, and thus that one must look for its derivation in appropriate phonetic-semantic combinations suggesting this sort of relationship. ${ }^{40}$ Against this association is the use of pilegesh in Ezek. 23:30 and its apparent reference to males. Another difficulty with Rabin's proposal, as he himself acknowledges, is the lack of an explicit "Philistine" connection for the Genesis narratives. Assuming that the "concubines" in these narratives are primarily slaves - specifically Hagar, Bilhah and Zilpah — he posits that later editors may have been reluctant to apply the term pilegesh to slave women. Their solution was thus to describe the women as both amab and ishah, to indicate their "in-betweenness" and lesser status. ${ }^{41}$ Again, this

37 Rabin, “Origin,” 360, 361.

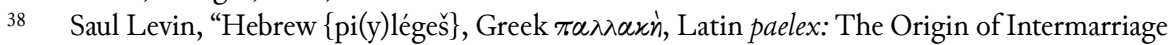
Among the Early Indo-Europeans and Semites," General Linguistics 23 (1983): 192, 194; Levin cites Herodotus, Histories, 6.137ff.

39 See Levin, “Hebrew," 193.

40 See, for example, Rabin, “Origin,” 363.

41 Rabin, “Origin,” 362-63. 
argument is circular, as there is nothing to indicate that the term pilegesh in any of the Genesis narratives means "concubine." As we have noted, Bilhah is in fact the only slave woman who is actually called a pilegesh, in the unusual verse Gen. 35:22, which describes her rape or seduction by Jacob's son Reuven. ${ }^{42}$ This argument also overlooks Judg. 19:1, in which the Levite's pilegesh is also called an ishah.

\subsection{THE PILEGESH AS A LITERARY TOPOS?}

Various scholars, more correctly in my opinion, focus on the biblical pilegesh as a key player in a particular kind of motif. Several of these scholars have posited a succession scenario. Brown, for instance, notes the similarity between some of the biblical pilegesh references and various incidents from Greek literature, in which the act of taking the father's concubine is primarily political. The pilegesh in his opinion is thus an "honorific" institution, with a key role in royal succession. ${ }^{43}$ Other scholars have similarly suggested a succession motif underlying the various biblical instances in which males have or demand intercourse with a pilegesh of their father or military superior: Reuven's rape/seduction of Bilhah, disqualifying him from firstborn status (Gen. 35:22, 49:3-4); Ish Boshet's accusation against Avner regarding Saul's pilegesh Ritzpah, leading to Avner's defection to David (2Sam. 3:7); Avshalom's public sex with David's pilagshim (2Sam. 16:2122), leading to Avshalom's disqualification from kingship; and Adoniahu's request to Solomon (through Batsheva) for Avishag, his father's consort, which leads to his death (1Kings 2:22). Solomon understood this request as an explicit threat to his kingship:

42 Rabin, “Origin,” 362, also argues that Gen. 25:6, which refers to the sons of Abraham's pilagshim, would include under the plural pilagshim both Qeturah, who is actually called a pilegesh in 1Chr. 1:31 (and a wife in Gen. 25:1), and Hagar, who is never explicitly called a pilegesh. As noted above (n. 130), there is a midrashic suggestion that Qeturah actually was Hagar, returned after Sarah's death, yet this is not at all clear in the biblical text. Further, the verse refers to the sons of the pilagshim being given gifts, yet Hagar's son Ishmael had already left.

43 Brown, Israel and Hellas, 68-70. Brown raises the further issue, which will not be examined here, of whether this particular motif has been borrowed. He suggests that the term was Hittite or Luvian in origin, was borrowed by the Philistines, and was borrowed from the Philistines by both Israel and Greece (ibid., 70). 
[The king replied to his mother:] Why request Avishag the Shunamite for Adoniah? Request the kingship for him! For he is my older brother...

The purpose of these actions, Patai suggests, is a claim on a superior's authority; in his opinion (based apparently on social anthropology assumptions) it was customary for a son, after his father's death, to marry all the father's wives and concubines with the exception of his own mother, "to demonstrate definitely the fact of succession." He suggests, based on the wording of Ezek. 22:10 ערות אב גלה בך (they have uncovered their father's nakedness in you [Jerusalem]), that the custom was still in practice in Ezekiel's time, though it was abhorred. ${ }^{44}$ Ariel, assuming that the pilegesh would have ranked somewhere between a semi-queen and slave-property, argued that such a status fitted her for this kind of role in securing succession. ${ }^{45}$

This assumption that the pilegesh was a key player in a succession motif would not explain other instances of the term, such as that in Ezek. 23:20. ${ }^{46}$ We may, however, consider the succession issue as simply one type of a more general class of aetiological motifs. Zakovitch and Shinan ${ }^{47}$ note that "sex stories" in general are frequently used in the Bible to justify later events, particularly a loss of status. In addition to the pilegesh stories, they note, for instance, the incest of Lot's daughters (Gen. 19:30-8), which explains the scornful attitude toward Ammon and Moav; the slaughter of the men of Shekhem by Simon and Levi to avenge the rape/seduction of their sister (Gen. 34:25, 49:5-7), which disqualifies them from first-born status after Reuven; and Amnon's rape of his half-sister Tamar (2Sam. 13),

44 Patai, Sex and Family, 101, 103; see also Matitiahu Tsevat, "Marriage and Monarchical Legitimacy in Ugarit and Israel," JSS 3 (1958): 242. In support of his contention, Tsevat also notes that the Targum to 2Sam. 16:21 (regarding Avshalom) translates niveshet with itgaryah, "to provoke, challenge." See also the suggestion of Tirzah Meacham, "The Missing Daughter: Leviticus 18 and 20," ZAW 109 (1997): 254-59, at 258, who argues that the Leviticus incest rules are both an apologetic for the behavior of the patriarchs and a priestly polemic against the house of David and its profligate ways.

45 Ariel, “The Pilegesh," 64.

46 On a plain reading, the incident of the pilegesh of Givah (Judg. 19-21) would also seem to be unrelated to succession; I shall argue below, however, that there may be a succession issue implicit in this story.

47 Yair Zakovitch and Avigdor Shinan, The Story of Reuven and Bilhab [in Hebrew] (Mif'ale hamehqar shel hamakhon lemada'e ha-yehadut; Jerusalem: Hebrew University, 1984), 1. 
which leads to his disqualification from kingship. We may thus propose that the pilegesh is one player in a number of "non-wife" relationships used for such aetiological stories. What characterizes pilagshim, whether male or female, is that they are "non-licit" sexual partners; as such, they attract danger, which leads to chaos. ${ }^{48} \mathrm{~A}$ more detailed examination of the use of pilegesh in certain passages will support the proposition that this term has a literary function rather than reflecting a specific status of concubine. We shall focus in particular on the apparent reference in Ezek. 23:20 to male pilagshim as well as the Bilhah-Reuven incident in Gen. 25:32 and the Judges 19-21 narrative.

\subsection{BIBLICAL EXAMPLES OF THREE INSTANCES OF PILEGESH AS TOPOS}

\subsection{A The Male pilagshim of Ezekiel. 23:20}

Ezekiel 23 concerns the unfaithfulness of Jerusalem and Samaria, represented metaphorically as the sexual licentiousness of the sisters Oholah and Oholibah with their "lovers," Egypt, Assyria, and Babylon. In verse 20, the pilagshim who are the object of Oholibah's attentions in Egypt are, on a plain reading of the text, males, whose profligate sexuality leads to the breaking of the proper relationship with God:

\section{ותעגבה על פלגשיהם אשר בשר חמורים בשרם וזרמת סוסים זרמתם}

She lusted for their pilagshim, whose members were like those of asses and whose flow [of semen, according to Rashi] was like those of stallions.

Rabin suggests that this use of a female term to refer to males may be a later, pejorative development. ${ }^{49}$ Yet it is just as reasonable to assume that it is the restriction of the term pilegesh to females which is the later development, much as the English term "concubine" has developed from

48 It is possible that narratives of such an offense or attempted offense with a wife - e.g., Pharaoh and Sarah, Joseph and Potifar's wife, David and Batsheva - have a different aetiological purpose.

49 Rabin, “Origin," 361. 
a generic term for a "lover" to a term restricted to females. ${ }^{50}$ It is in fact in postbiblical translations and commentaries that the term pilegesh is restricted to females, a restriction that causes particular difficulties for those commenting on the Ezekiel verse.

The LXX to Ezek. 23:20 seems to acknowledge the "maleness" of the

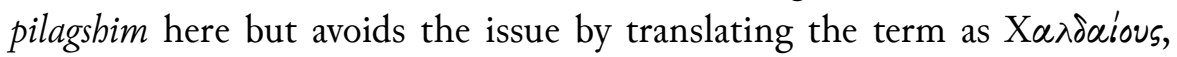
"Chaldeans"; other interpretations simply reject the idea of male pilagshim. The Targum to Ezekiel has:

ואתרעיאת למהוי שמשא* להון דבסר חמרין בסריהון וצחנת סוסין צחנתהון

[ שמוטא in some editions*]

She took pleasure in being a servant ${ }^{* 51}$ to them whose flesh was the flesh of donkeys, and whose flow of semen was the flow of horses

[*in some editions 'abandoned']

In an extended comment on this verse, Radak explains that it is appropriate to refer to female lewdness (a characteristic associated, of course, only with pilagshim, not wives) using male sexual terms:

ותעגבה על פלגשיהם - פירשו המפרשים פלגשים עבדיהם כי פלגשים במקום הזה אנשים

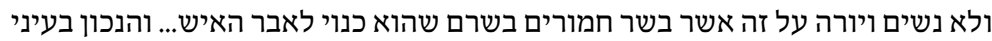

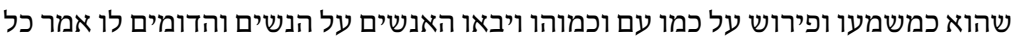

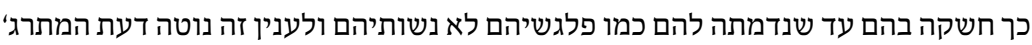

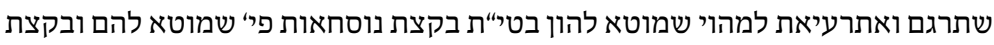

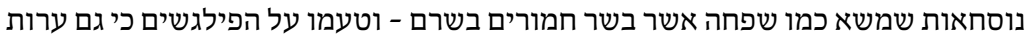
הנקבה מכונה בלשון בשר...

And she lusted after their pilagshim: The commentators interpreted their pilagshim as 'their male slaves' because pilagshim in that place were men, not women; and this is shown by whose flesh is like the flesh of donkeys, which describes the male member... In my view the correct [interpretation] is the

50 In current usage according of The New Shorter Oxford English Dictionary on Historical Principles (Oxford: Clarendon, 1993), a "concubine" is a female: "one who cohabits with a man without being his wife," a "kept mistress," or, in polygamous societies, a "secondary wife." In Late Middle English, however, the term also referred to a woman's male lover (ibid.). Perhaps "consort" would be an appropriate term.

51 Here, too, there is a sexual connotation in the root $\check{S} M \check{S}$. 
literal one. The interpretation of al is like $i m$, such as 'the men came with the women' and similar. [The verse thus stated]: She lusted after them to such an extent that she seemed to them like their pilagshim, not their wives. The [Aramaic] translator took this view of the issue, translating ואתרעיאת למהוי שמוטא להון, with a tet in several versions, whose translation is 'she was abandoned to them,' and in several versions שמשא, like a female slave. Their flesh is like the flesh of donkeys - its usage is with respect to the pilagshim, because female genitalia are also described using terms like 'flesh'...

Other commentaries and translations twist the verse, so as to render the term pilegesh as an abstract noun meaning "concubinage." 52 Rashi, for instance, has:

ותעגבה על פלגשיהם: על פלגשות' להיות להם לפלגש

And she lusted after their pilagshim: after [their] concubinage, to be a pilegesh to them.

The Vulgate translates על פלגשיהם as super concubito eorum (after lying with them).

Yet the context here clearly suggests a female associated with several males. A halakhic midrash in fact confirms that there was a belief, at least among later sages, that the Egyptians engaged in such polyandrous practices. This midrash comments on the introduction to the incest provisions in Leviticus 18, which contains a general warning against following the practices of Egypt and Canaan (v. 3):

כמעשה ארץ מצרים...וכמעשה ארץ כנען...לא תעשו

You shall not copy the practices of the land of Egypt...or the land of Canaan...

The sages set out their understanding of the nature of these practices

52 Certain English translations are less reticent, using general terms for sexual partners such as "paramours" (KJV) or "profligates" (Jerusalem Bible). The Yiddish translation of Aaron Bergmann, The Old Testament in Hebrew and Yiddish (London: British and Foreign Bible Society, 1912), is quite direct, translating the word as קעבסמענער, "half husbands," apparently the male equivalent of the female קעבסוויב, "half wife" or "concubine." 
(Sifra Abarei Mot 9:8, Weiss p. $85 \mathrm{~d}^{53}$ ):

ומה היו עושים? האיש נושא לאיש, והאשה לאשה, האיש נושא

אשה ובתה, ואשה ניסת לשנים.

And what did they do? A man would marry a man, a woman [would marry] a woman, a man would marry a woman and her daughter, and a woman would marry two [men].

We may thus conclude that the pilagshim in this verse are male "consorts," and it is the (immoderate) association with them that leads to censure on the part of the prophet.

\subsection{B Gen. 35:22: Bilbah as pilegesh}

This verse is placed after a description of the travels of Jacob and his entourage south from Padan Aram. At Bethel (later part of the territory of Ephraim) Jacob is renamed "Israel"; the text then recounts the birth of Benjamin on the way to Efrat (Bethlehem in Judah, which is in a direct line south). Rachel dies after this birth, and it is then that one would expect a summary such as "the sons of Jacob were twelve." Instead, the Bible interrupts this summary with the record of an incident between Reuven and Jacob's "slave-wife" Bilhah. This passage is both disturbing in content and unusual in structure:

ויהי בשכן ישראל בארץ ההוא וילך ראובן וישכב את בלהה פילגש אביו וישמע ישראל

ויהו בני יעקב שנים עשר ישר

And when Israel dwelt in that land, Reuven went and lay with Bilhah his father's pilegesh and Israel heard

[There is here a lacuna in the text, marked in some printed editions with a

53 W. Ward argues based on linguistic evidence that it is in fact unlikely that "concubinage" existed in Pharaonic (Old and Middle Kingdom) Egypt, suggesting that the existence of harems and concubinage would have been inconsistent with the monogamy and legal equality that were the rule at this time. William Ward, "Reflections on Some Egyptian Terms Presumed to Mean 'Harem, Harem-Woman, Concubine,” Berytus 31 (1983): 68,74 . 
פ, the Masoretic sign for parashab petubab indicating the end of a section. ${ }^{54}$ There are also two different cantillation signs for the word ישראל: a sof pasuq, i.e., a full stop, associated with eastern MS traditions, and an etnạ̣ta, major pause/comma, associated with western MS traditions. ${ }^{55}$ Both are disjunctive accents. ${ }^{56}$ ]

And the sons of Jacob were twelve.

The strange insertion at this point of the incident of Bilhah and Reuven, the physical lacuna in the text, and the apparent lack of reaction by Jacob suggest to some scholars that the text has been deliberately manipulated: material has been left out, or the abruptness of the text is meant to suggest that the rest of the story is to be found elsewhere. ${ }^{57}$ I suggest that there is a further puzzle in the use of the words "his father's pilegesh" to describe Bilhah; the description seems, on the one hand, superfluous, and on the other hand contradictory, given that she has already been called his ishah. Further, the word is not used to describe Hagar or Zilpah, though their situations were similar.

The lacuna, called a pisqa be-emtsa pasuq $[=P B P]$, is a section division occurring in the middle of a verse, which is presumed to be the result of exegetical activity, i.e., someone's subjective assessment that there is a change in the content of the text, requiring a break. ${ }^{58}$ Source criticism in fact assigns the verse to two different strata: $22 \mathrm{a}$ is assigned to $\mathrm{J}$ and $22 \mathrm{~b}$ to P. In the opinion of some scholars, however, this structure suggests the possibility that something has actually been dropped out of the text. ${ }^{59}$ The possibility of variant readings of this verse is indicated by the LXX rendition, which attributes a reaction to Jacob with the words xai roungov

54 See, e.g., Emanuel Tov, Textual Criticism of the Hebrew Bible (Minneapolis:

Fortress, 1992), 50-51, for a discussion of the origins of these text divisions.

55 Zakovitch and Shinan, The Story of Revuen and Bilhah, 23.

56 These signs indicate a separation from the following words, with the sof pasuq (silluq) being "stronger" than the etnabta. See, e.g., Tov, Textual Criticism, 69.

57 See, e.g., Shemaryahu Talmon, "'Pisqah Be'emșa Pasuq' and 11QP5a," Textus 5 (1966): 18, who suggests that the lacuna in Gen. 35:22 points to $1 \mathrm{Chr}$. 5:1.

58 Tov, Textual Criticism, 51, 54-55. According to Tov (ibid., 51), the practice found in the Masoretic group of texts of using spaces to indicate sections is also known from much earlier texts, including biblical texts found among the Dead Sea documents.

59 These arguments are summarized in Zakovitch and Shinan, The Story of Reuven and Bilhah, 23. 


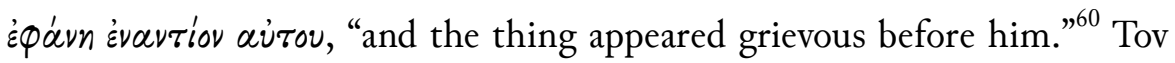
suggests that this addition is actually a Hebraism, a translation of the phrase וירע בעיניו (and it was evil in his eyes), similarly translated by the LXX in Gen. 38:10; it was thus in his view likely based on a variant text which had these additional words. ${ }^{61}$

The motive behind such variations is similarly speculated upon by scholars, and is generally assumed to be related to the aetiological function of the incident. As the text was presumably manipulated, one wonders whether the reference to Bilhah as a pilegesh was deliberately inserted in order to give this incident the form of an aetiological "set piece."

Certainly the episode of Bilhah and Reuven was already represented in the Bible as the cause of Reuben's disqualification from the status of firstborn. Genesis 49, for instance, records Jacob's blessings for his sons; verse 4 , itself something of a circumlocution, provides for Reuven:

פחז כמים אל תותר כי עלית משכבי אביך אז חללת יצועי עלה

Boiling over like water - you will not surpass; you mounted your father's bed(s), and then you committed defilement - he mounted my couch. ${ }^{62}$

1Chronicles 5:1-3 gives the similarly convoluted statement: ${ }^{63}$

Translation of L. Brenton, The Septuagint Version: Greek and English (Grand Rapids, Mich.: Zondervan). We may note that Targum Yonatan also attributes a reaction to Jacob; see note 65.

61 Emanuel Tov, The Text-Critical Use of the Septuagint in Biblical Research (Jerusalem Biblical Studies 8; Jerusalem: Simor, 1997), 84.

62 The verse has a number of unusual features aside from its obscure meaning. Gesenius suggests that the absence of a verb in the first phrase is a feature of exclamatory speech. See E. Kautzsch, Gesenius' Hebrew Grammar (revised by A. E. Cowley; Oxford: Clarendon, 1970), section 147c. As G. Brooke, "4Q Commentary on Genesis A," in Qumran Cave 4, XVII, Parabiblical Texts, Part 3 (DJD 22; Oxford: Clarendon, 1996), 204, has noted, a verb in 2 m.s. perf. is found in other texts. The Samaritan Pentateuch [=SP], for instance, based on the MS used by Abraham Tal, The Samaritan Targum, has פחזת (you were hasty) instead of the noun פחז; the LXX has $\varepsilon \xi \cup \beta \rho เ \sigma a s$ (you were insolent). Other features noted are the use here, as in Ruth 2:14, of תותר instead of the expected תותיר (SP has the use of the plural משכבי, and the abrupt transition from 2nd to 3rd person, suggested to be a feature of poetic speech (Gesenius, 53n, 124b, 144p).

63 The comments on Reuven appear to take the form of an aside inserted into the main text. Zakovitch and Shinan, The Story of Reuven and Bilhah, 14, suggest that vv. 1-3 are structured as a chiasmus. 
ובני ראובן בכור ישראל כי הוא הבכור ובחללו יצועי אביו נתנה בכורתו

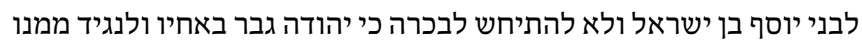

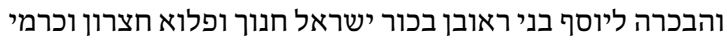

And the sons of Reuven, the firstborn of Israel - though he was the firstborn, in his defiling of the couches of his father his birthright was given to the sons of Joseph the son of Israel, so that he was not included in the birthright; though Judah prevailed over his brothers, and a leader [came] of him, the birthright was Joseph's - the sons of Reuven, the firstborn of Israel, were Hanokh and Palu, Hetzron and Karmi.

Zakovitch and Shinan point also to a possible relationship of the incident to Deut. 33:6, a part of Moses' blessings of the tribes, which states:

יחי ראובן ואל ימת ויהי מתיו מספר

Let Reuven live and not die, but his men shall be few.

They suggest that this verse was possibly aware of a version of Gen. 35:22 that referred to a curse upon Reuven condemning him to death and attempted here to blunt its effect; ${ }^{64}$ a later editor actually removed the curse from 35:22, which accounts for its odd structure.

These circumlocutions and the sense that something has been left out of Gen. 35:22 suggest that the biblical editors already had difficulty with the precise nature of Reuven's sin, and consequently with the role of Bilhah. Did Reuven commit incest with his father's wife? Was the phrase פלגש אביו (his father's pilegesh), inserted precisely to mitigate such an implication? Was it inserted because this story was seen as a well-known moral lesson in which the pilegesh plays an important role? There are two pieces of evidence that support the latter interpretation.

Qumran document 4Q252 reacts to the mention of a pilegesh in this verse. The document in general highlights certain Genesis narratives in order to clarify or re-present them. ${ }^{65}$ Column iv of this document contains

64 Zakovitch and Shinan, The Story of Reuven and Bilbah, 14.

65 Robert Eisenman and Michael Wise, The Dead Sea Scrolls Uncovered (New York: Penguin Books, 1992), 77. 
two references to pilagshim: it juxtaposes Timna (the pilegesh of Eliphaz, the son of Esau, in Gen. 36:12) and Bilhah (though, as we have noted, she is called the pilegesh of Reuven's father only in Gen. 35:22): ${ }^{.6}$

תמנע היתה פילגש לאליפז בן עשיו ותלד לו את עמלק הוא אשר הכ[ה] שאול [...] כאשר

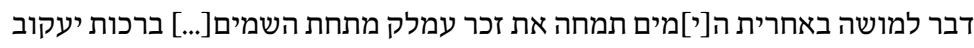

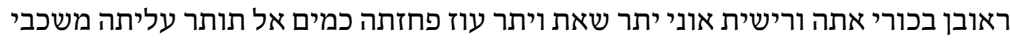

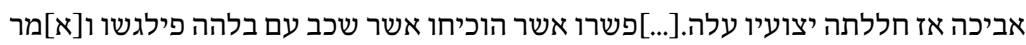

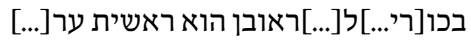

Timna was the pilegesh of Eliphaz, the son of Esau. And she bore him Amaleq, he whom Saul destroyed [...] as He spoke to Moses: In the latter days you will wipe out the memory of Amaleq from under the heavens [Deut. 25:19] [...] The blessings of Jacob: Reuben, you are my firstborn and the first fruits of my strength, excelling in dignity and excelling in power. You were unstable as water; you shall no longer excel. You went up onto your father's bed. Then you defiled. He went up on bis couches [... ] its interpretation is ${ }^{67}$ that he reproved him in that he lay with Bilhah his pilegesh. And he [s] aid [My] first[born.....]Reuven he was the first $[. .$.

I believe that this passage serves, among other possible functions, ${ }^{68}$ as a polemic against pilagshim. Two pilegesh references from Genesis are linked to each other and to Jacob's blessing by means of two types of commentary: the use of other biblical references (in this case from Deuteronomy) to explain the verses in Genesis, and a pesher-type commentary explaining the meaning of $49: 4 \mathrm{~b}$ as a reproof. ${ }^{69}$ Through these various juxtapositions, the text makes an explicit aetiological connection between a relationship with

66 The Hebrew is taken from Brooke, "4Q Commentary," 203-4.

67 According to the editor, this is a standard introductory formula in a pesher (204, note L. 5).

68 Compare, e.g., the suggestion by Eisenman and Wise, The Dead Sea Scrolls Uncovered, 83-85, that the document is ultimately a Messianic pronouncement with a collateral condemnation of fornication, and the contrary suggestion by Moshe Bernstein, "4Q252: From Re-Written Bible to Biblical Commentary," JJS 45 (1994): 124, to consider the document simply as a series of commentaries and to avoid seeking "artificial unifiers" in the text.

69 Bernstein, “4Q252," 19, questions the use of the pesher form here, on the assumption that this form is connected with "sectarian commentary"; he posits, based on this sample, that the use of the pesher form may be broader. 
a pilegesh and later loss of status, or worse; it reinforces the idea that the result of dealing with such women is disaster - the destruction of one's descendants (Amaleq, supposedly the descendant of Esau, by Saul in 1Sam. $14: 48 ; 15: 3,7$ ) or the removal of the rights of the firstborn (from Reuven, in Gen. 49). Of further interest are the variants in the biblical lemmata, particularly the use of שכב עם (lay with) for the MT שכב (lay) in Gen. 35:22, פחזתה (you were unstable) for the MT פחז (he was unstable) in Gen. 49:4. ${ }^{71}$ This might be further indication that the biblical verses in question were unstable.

A second piece of evidence is found in Targum Neofiti. In the edition of Diez Macho the words פילגש אביו (his father's pilegesh) are left untranslated in the primary $\mathrm{MS},{ }^{72}$ which has:

והוי כדי שרון ישראל בארעא ההיא ואזל ראובן וישכב ית בלהה ושמע ישראל והוון בנוי יעקב תרין עשר שרון יכרי

The words פילגש אבוי have been added as an interlinear gloss.

Diez Macho and other scholars have suggested that this omission is in fact a reflection of the mishnaic prohibition in $m M e g .4: 10$; this restricts the public dissemination of the Bilhah-Reuven incident, among others:

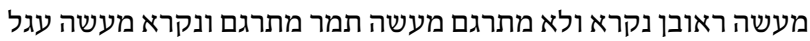
ראשון נקרא ומתרגם והשני נקרא ולא מתרגם ברכת כהניא מלגים מעשה דוד ואמנון לא נקראין ולא מתרגמין

The incident of Reuven is read [in public] but not translated. The incident of Tamar [and Judah, in Gen. 38] is read and translated. The first incident of the calf [Exod. 32:1-20] is read and translated; the second [the continuation of the chapter in vv. 21-35] is read but not translated. The blessing of the

70 It is not clear whether different nuances are implied by את מכת and The Bible uses both, as well as various prepositions with שכל including (as in Gen. 39:10). It is perhaps significant that three instances referring to a שכבת זרע also use the particle את (Lev. 15:18, 19:20, and Num. 5:13). Brown, Israel and Hellas, 68, suggests that the difference might be comparable to that in modern "vulgar" English between "lay" and "lie with."

71 As noted above (n. 58), both the SP and LXX have a verb in 2 m.s. perf.

72 This Targum uses לחנתה elsewhere in Genesis in the same manner as Onkelos for pilegesh and certain amab/shif̣ab references to Bilhah and Zilpah; for Re'umah, however (Gen. 22:24), it uses פלקה. 
priests [Num. 6:24-6] and the incident of David and Amnon [with respect to Tamar, according to the Gemara (b. Meg. 25ab), in 2Sam. 13:1] are not read and not translated.

The precise application of this rule is unclear, particularly whether the prohibition referred to the written Targumim. An expanded version of the ruling is found in $t M e g$. (Lieberman) 3:35, associated with R. Haninah ben Gamliel, a second generation tanna: ${ }^{73}$

מעשה ראובן נקרא ולא מיתרגם ומעשה בר' חנינה בן גמליאל שהיה

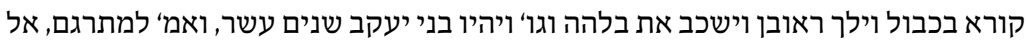

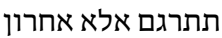

The incident of Reuven is read but not translated. And it happened that R. Haninah ben Gamliel, who used to read in $\mathrm{Kabul}^{74}$ : ...Reuven went and lay with Bilhah, etc., and the sons of Jacob were twelve, told the translator: 'Translate only the last [part].'

What is included in the "etc.," however, is not clear from any of the MSS cited in the apparatus. ${ }^{75}$ We may note also that the Aramaic Targumim do actually translate this verse, more or less literally (TY adds an interpretation that is found in bShabb. 55b, among other places. ${ }^{76}$ ) McNamara, however, claims that all the restricted texts in $m M e g$. are missing in Neofiti, and thus that this Targum is dependent on a tradition

73 In the opinion of P. S. Alexander, “The Rabbinic Lists of Forbidden Targumim," JJS 27 (1976): 180, R. Haninah is the source of this ruling.

74 The first printed edition has בעכו

75 MS עשר th missing the words from בל את to buch shortening of verse quotations is common in rabbinic literature.

76 This talmudic reaction will be discussed below. The TY reads:

והוה כד שרא ישראל בארעא ההיא ואזל ראובן ובלבל ית מצעא דבלהה פילקתיה

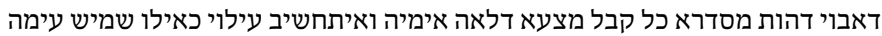

ושמע ישראל ובאיש ליה ואמר ויי דילמא נפיק מיני דיני פסולא...

And it was when Israel dwelt in that land, Reuven went and disarranged the bed of Bilhah, his father's concubine, which was arranged alongside the bed of his mother Leah; and it was attributed to him as if he had had intercourse with her. And Israel heard, and was ashamed, and said: 'Woe lest an unworthy person is descended from me...' 
abiding by the mishnaic legislation. ${ }^{77}$ Alexander too argues that the pattern of omissions in Targum Neofiti confirms a rabbinic interest in regulating the Targum in general, and that this Targum was directly edited or followed a variant that had been edited. Zakovitch and Shinan, ${ }^{78}$ noting the mixture of Aramaic and Hebrew, especially the use of the word וישכב (he lay), suggest that in fact none of the "offending" part of the verse was translated at first; various hands later translated different words. This explanation might account for the mixture of languages, yet it would seem that none of the explanations is sufficient to explain why only the words פילגש אביו are missing, and how such an omission would be seen as fulfilling the requirements of $m M e g$ 4:10. It is possible, on the one hand, that the redactor thought that simply omitting these words would avoid shedding light on the situation; on the other hand, it is also possible that there was a textual tradition used by the translator that did not have these words in the original Hebrew. Again, such a possibility suggests that the word pilegesh in the biblical text plays a specific role. I would argue, therefore, that there is support for the possibility that the term pilegesh was not original to the verse in all MT versions and was deliberately added to impart a stereotypical moral lesson.

It is interesting to note that much extrabiblical and postbiblical writing on this incident is concerned with dissociating Reuven from any suggestion of incest. To the extent that these discussions reflect on Bilhah's status, I shall discuss them further in chapter 7 , as a further indication that Bilhah remained a biblical "insider" until relatively late.

\subsection{The ishab pilegesh of Judges 19}

The last section of the book of Judges, ending with the civil war between Benjamin and the rest of the tribes (chs. 19-21), begins in chapter 19 with the bizarre story of the ishab pilegesh. Judges 19:1-3 describe her relationship with a certain Levite:

77 Martin McNamara, The New Testament and the Palestinian Targum to the Pentateuch (Rome: Pontifical Biblical Institute, 1966), 47.

78 Zakovitch and Shinan, The Story of Reuven and Bilbah, 15-16. They note (p. 16) that in the related verse Gen. 49:4 (Jacob's blessing of Reuven), the sin of Reuven is also left untranslated, and may have been thought to have been included in the prohibition in $m M e g$. 
ויהי בימים ההם ומלך אין בישראל ויהי איש לוי גר בירכתי הר אפרים

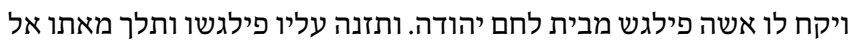

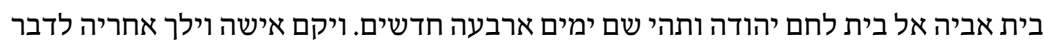

על לבה להשיבו

qere*

In those days, when there was no king in Israel, there was a Levite man living in the foothills of Mount Ephraim; he took an ishab pilegesh from Bethlehem [in] Judah. And his pilegesh ended her relationship with him ${ }^{79}$ and went away from him to her father's house to Bethlehem [in] Judah and was there four whole months. And her husband arose and went after her to speak kindly to her and to bring her back [according to the qere]...

On their return journey, lodging in Givah with an Ephraimite, they are beset by a mob of Benjaminites, who demand that the Levite be sent out to them to be used sexually. The host sends out the Levite's pilegesh instead; she is repeatedly raped and is found lying by the door in the morning (Judg. 19:27-8):

ויקם אדניה בבקר ויפתח דלתות הבית ויצא ללכת לדרכו והנה האשה פילגשו נפלת פתח

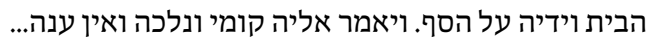

And her lord rose up in the morning, and opened the doors of the house, and went out to go his way; and behold his ishab pilegesh was fallen down at the entrance of the house, and her hands were on the threshold. And he said to her, 'Get up and let us go.' But there was no answer...

The Levite cuts her body into twelve pieces and sends them throughout Israel, inviting vengeance on Givah. A civil war ensues in which the tribe of Benjamin is nearly destroyed. Having vowed not to give their daughters in marriage to any Benjaminites, the remaining tribes nonetheless arrange to provide the remnant with women taken forcibly from Yavesh Gilad, and thereafter invite the Benjaminites to replenish their supply of wives by setting upon the women at the yearly festival at Shiloh.

It is generally recognized that there is more to this narrative than simply

79 This is not the usual translation of ותזנה עליו which is usually taken to imply some type of harlotry or other sexual misbehavior. I shall explain my translation in more detail below. 
the supposed "decadence" of later Hebrew literature. ${ }^{80}$ There is evidence of a deliberate attempt to emphasize the macabre and dehumanizing aspects of the narrative, especially in chapter 19 , through various devices, many of which have been discussed by scholars: the use of darkness as a portent of danger and as associated with the sexuality of "unusual" women; ${ }^{81}$ the anonymity of the participants; the exaggerated, nightmare-like delay of the group's departure from Bethlehem and their consequent failure to reach shelter before dark; ${ }^{82}$ and parody or mocking of other biblical events, through the use of similar themes or theme words: the young lad, pair of donkeys, and knife used by the Levite recalling the two young men, the donkey, and the knife accompanying Abraham on his way to sacrifice Isaac (Gen. 22:3, 10); the offer of a woman's sexual services in order to save a male guest from homosexual rape, as at Sodom (Gen. 19:8); Saul's cutting up of oxen into twelve pieces to rally the people, this time in defense of Yavesh Gilad (1Sam. 11:7). ${ }^{83}$

As noted by Robert Boling, Judges (Anchor Bible 6A; Garden City, New York: Doubleday, 1975), 278, citing earlier opinions of Wellhausen and Moore.

81 See, e.g., Weston Fields, "The Motif 'Night as Danger' Associated with Three Biblical Destruction Narratives," in Sha'arei Talmon: Studies in the Bible, Qumran and the Ancient Near East Presented to Shemaryahu Talmon (ed. M. Fishbane and E. Tov; Winona Lake, Ind.: Eisenbrauns, 1992), 22, 26 who notes a similar use of darkness with respect to the destruction of Sodom in Gen. 19 and the final plague in Exod. 12:29 ("And it came to pass at midnight"). He describes the association of night and irregular types of female sexuality as an "allo-motif" running throughout the Bible.

82 See. e.g., Yair Zakovitch, “The Literary Paradigm Three-Four in the Bible” [in Hebrew] (Ph.D. diss., Hebrew University, 1977), 334, 336, who suggests that the impression of a deliberate manipulation of time is created in the narrative by a variation of the "threefour" pattern that he argues is prevalent in the biblical text. The Levite's five-day stay at his father-in-law's has three distinct periods: the first three days; the fourth day, when by the usual three-four pattern one would expect the group to leave; and the fifth day, when the group actually leaves. The description of the fourth day is marked by a lengthening of phrases, and the fifth by a shortening of phrases and feeling of urgency; the effect is thus to create peaks and troughs of tension.

83 See, e.g. Jeremiah Unterman, "The Literary Influence of 'The Binding of Isaac' (Genesis 22) on 'The Outrage at Gibeah' (Judges 19)," Hebrew Annual Review 4 (1980): 161-66, esp. $162-63$, on the parallels to the sacrifice of Isaac; Ken Stone, "Gender and Homosexuality in Judges 19: Subject-Honor, Object-Shame?” JSOT 67 (1995): 87-107, at 100, on the theme of homosexual rape as an act of asserting relative power relations and the rape of the Levite's concubine as a proxy for this act; Yairah Amit, "The Story of the Pilegesh in Givea in the Hidden Dispute Against the Kingship of Shaul (Judges 19-21)” [in Hebrew], Bet Miqra 37 (1991) on the use of place names and events reminiscent of Saul narratives 
The number of such devices and allusions suggests that their inclusion is not coincidental and that they are meant to draw the reader's attention to non-explicit aspects of the story. As Stone has noted, ${ }^{84}$ however, this very complexity leaves open the possibility for a variety of interpretations, at different levels of reading or with different socio-historical foci. Earlier commentators attempted to rationalize aspects of the story. Josephus and Pseudo-Philo, for instance, both attempt to justify the treatment of the pilegesh. Pseudo-Philo asserts not only that both the "concubine" and the Levite were dragged out by the mob, but that the woman was being punished because she "committed sin with Amalekites" (45:3). ${ }^{85}$ Josephus specifically calls the woman $\tau \dot{\omega} \nu$ rov'́ $\omega \nu$ (his wife), and states that she left the Levite because they quarreled; the Benjaminites demanded her and took her by force, and she was ashamed to show her face to her husband (Ant. 5:142). Certain rabbinic interpretations emphasized the story as a revelation of divine justice. According to a passage in bSan. 103b, the Israelites were overcome by the Benjaminites because they valued human honor (i.e, the Levite's) over divine honor:

אמר להן הקב“ה הניחו לו שפתו מצויה לעוברי דרכים ועל דבר זה נענשו אנשי פ“בג אמר

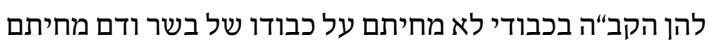

The Lord Blessed-Be-He said to them: 'They left him [Micah, in Judg. 18] alone, as his bread was available to travelers; but on this matter the people of the pilegesh of Givah were punished.' The Lord Blessed-Be-He said to them: 'You did not protest on behalf of my honor, but you did protest about the honor of flesh and blood.'

Tanbuma Vayeshev 2 similarly contrasts the Israelites' avenging of the human affront in Judges 19-21 with their failure to act against Micah's idol in the immediately preceding chapter of Judges:

תדע לך כח החרם שהרי השבטים שקנאו על פלגש בגבעה ולא קנאו על פסל מיכה הרגו בהן בני בנימין פעם ראשונה ושניה ושלישית...

in 1 Sam.

84 Stone, "Gender and Homosexuality," 88-89.

85 This translation is by Harrington, "Pseudo-Philo." 
Know the power of the ban: The tribes who were incensed regarding the pilegesh of Givah but not about Micah's idol had their people slain by Benjamin once, twice, three times... ${ }^{86}$

Certain scholars have interpreted the three chapters from a political perspective, either as reflecting in some degree actual events, or as promulgating some sort of political message.

Other scholars prefer to see the elements of the narrative as the "materialization of a social reality of which they are a part and to which they respond." ${ }^{\prime 8} \mathrm{Bal}$, in particular, emphasizes the role of the pilegesh within the larger social reality apparently represented in the book of Judges; the coherence of this book, in her view, lies not in a particular political chronology but in the systematic violence against women portrayed throughout the text. ${ }^{89}$ This perspective helps to focus on what from our point of view are the essential questions in chapter 19: Why a pilegesh, and what point do her rape and murder serve in the story? We may posit that it is her precariousness that makes her appropriate as a victim, again highlighting the use of the idea of the pilegesh as a player in a set piece.

We may note first that the focus on the woman and her "unusualness" is highlighted by the use of inconsistent kinship terminology. In Judg. 19:27 the Levite is referred to as the woman's adon, "lord," a term which might suggest a master-slave relationship. Yet up to this point he has been called simply her ish, "man" or "husband" (e.g., 19:3, 20:4); the relationship

86 Pseudo-Philo also proposes a linkage of the Micah and Givah texts: the Israelites were punished because they overlooked the sin of Micah's idol while allowing themselves to be provoked about the fate of the concubine (45:6, 46:7).

87 See, as a representative sample, Jan Fokkelman, "Structural Remarks on Judges 9 and 19," in Sha'arei Talmon, 43, who argues that the chapters are a pro-monarchy polemic, with the phrase "there was no king in Israel" framing the narrative in its first and last verses (19:1 and 21:25) in order to underline the social chaos that results from the absence of a king; Amit, "The Story of the Pilegesh in Giveah," 118, who sees the narrative as proDavidic, serving to emphasize the ineffectiveness of the Benjaminite Saul, who is from Yavesh Gilad (1Sam. 10:26), as compared to David, of the family of Boaz, who is related to Naomi's husband from Bet Lehem (Ruth 4:22); and Boling, Judges, 278, who sees the narrative as a postexilic exhortation to return to a united Israel and give up the antiquated notion of a loosely organized tribal confederation.

88 See Mieke Bal, Death and Dissymmetry: The Politics of Coherence in the Book of Judges (Chicago: University of Chicago Press, 1988), 6.

89 Bal, Death and Dissymmetry, 5. 
between the Levite and the woman's father is expressed with boten/hatan, "in-law" (e.g., 19:4, 5, 7, 9). The woman herself is referred to in various ways: with respect to the Levite, as an ishab pilegesh (a term unique to chapter 19, vv. 1, 27, and perhaps a contradiction in terms, if we take it as "consort-wife"), as simply pilegesh, or as simply ishab; with respect to her father, as na'arab; and by the host as an amab (19:19). The unusual relationship is heightened by the use of the ambiguous verb זנה ZNH in verse 2, sometimes translated here with reference to harlotry (e.g., KJV: "played the whore"), or as denoting faithlessness, particularly sexual. Rashi, for instance, has:

זנתה מביתו אל החוץ כל לשון זנות אינו אלא לשון יוצאת נפקת ברא

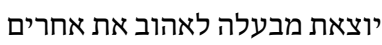

She went out from his house to the outside; the language of zenut is simply 'one who goes out,' [i.e.,] a prostitute — she goes out from her husband to be a lover to others.

The Targum to Judges has ובסרת עלוהי, "she slighted him” (Jastrow).

Bal has challenged, correctly I believe, ${ }^{90}$ the conventional meanings assigned to pilegesh as "concubine" and zonab as associated with harlotry. She interprets this chapter, among other narratives in Judges, as reflecting the tensions arising from the change between patrilocal marriage, in which the wife remains with her father, her natural "owner," and virilocal marriage, in which the wife goes with her husband, a culturally-assigned owner.' Bal accepts the interpretation of pilegesh as a woman in the beena-type, patrilocal marriage described by Morgenstern (1929, 1931); the pilegesh in Judges 19 had challenged the virilocal system by leaving her husband (the implication of the term $\mathrm{ZNH}$ here $)^{92}$ to return to her father, and had to

90 In my article, “A Re-embracement of Judges 19: Challenging Public-Private Boundaries," in Vixens Disturbing Vineyards: Embarrassment and Embracement of Scriptures, Festschrift in Honor of Harry Fox leVeit Yoreh (ed. Tzemah Yoreh et al.; Boston: Academic Studies Press), 53-64, I argue again that "consort" is a better translation of pilegesh and that עליו should be translated here as "she went away in anger."

91 Bal, Death and Dissymmetry, 5, 89.

92 On the question of the etymology of the biblical root $Z N H$, see, e.g., L. Koehler and W. Baumgartner, The Hebrew and Aramaic Lexicon of the Old Testament (Leiden: Brill, 1995), s.v. זנה II. The first root is connected both with the idea of harlotry 
be eliminated. ${ }^{93}$ The "faithlessness" exhibited by the pilegesh would thus be interpreted differently by father and husband."

While I do not wish to contest in detail Bal's proposition, I think that her definition of pilegesh is too narrow; as Exum, among others, has noted, the idea of a beena-wife would not fit all biblical uses of pilegesh. ${ }^{95}$ I do, however, agree that the vagueness of the terminology is deliberate, and that, as she notes, the story is structured around the tension between "inside" and "outside" the house. ${ }^{96}$ I suggest that Judges 19-21 again associates the pilegesh, the woman outside "normal" boundaries, with an aetiological challenge to authority (whether or not this passage represents an actual event). In this case there is an attempt by representatives of the youngest brother Benjamin (through the men of Givah) to challenge the authority of the older brother Judah, now the "legal" firstborn, through the medium of the pilegesh of Bethlehem, a representative of Judah. Judah's priority, we may note, is emphasized both at the beginning and at the end of this book, and the language is similar: Judah is nominated by God as first to the attack at the conquest (Judg. 1:1-2 and similarly nominated during the civil war (Judg. 20:18).

There is a further intra-biblical allusion to another "unusual" woman that reinforces the idea that the use of the pilegesh is an intentional literary device. Judges 19:27, quoted above, describes the action of the woman's husband (now called her "lord") after her night of terror: ויפתח דלתות הבית (and he opened [vayiftab] the doors of the house); these words specifically recall the vow of Yiftah in Judg. 11:31 that ultimately leads to the sacrifice

and the idea of apostasy. The authors connect the second root with Akkadian zen $\hat{u}$, "to hate," a term found in Mesopotamian "divorce” clauses (see, e.g., CT 6 26a, 11. 9-12, as translated by Westbrook, Old Babylonian Marriage Law, 117). They also note, however, that the meaning "to be apostate" associated with the first root may be an extension of the meaning "to hate." One might posit that the biblical language of zenut implies in general an idea of moving apart from the Deity or a person, whether the motive is faithlessness, hatred, or adultery. It thus need not imply the specific sin of harlotry.

93 Bal, Death and Dissymmetry, 85, 92-93.

$94 \mathrm{Bal}$, Death and Dissymmetry, 88. Bal notes the definitions of zonah given by Koehler and Baumgartner as including a husband who does not live with his wife's tribe. In the 1995 edition of this work, however zonab is defined simply as "a woman occasionally or professionally committing fornication, prostitute, harlot."

95 J. Cheryl Exum, Fragmented Women (Valley Forge, Pa.: Trinity, 1993), 177 n. 13.

96 Bal, Death and Dissymmetry, 90. 
of his daughter:

והיה היוצא אשר יצא מדלתי ביתי לקראתי בשובי בשלום מבני עמון

והיה לה' והעליתיהו עולה

...whatever comes out from the doors of my house to meet me upon my safe return from the Ammonites will be God's, and I will sacrifice it as an 'olah.

The threshold is significant in both stories. Exum suggests that the pilegesh text is a castigation regarding of the dangers to an autonomous woman, ${ }^{97}$ one who has violated the boundaries between the domestic and the public spheres by leaving her husband. As Bal notes: "The boundary between inside and outside gives rise to 'an almost obscene conflation of private and public. It brings with it all the solitude of absolute privacy with none of its safety...”" Possibly the involuntary and coerced "prostitution" of the pilegesh serves as an ironic contrast to her autonomy and results in her being permanently excluded from the household, permanently on the threshold..$^{99}$ The "proper" order is restored by allowing the taking of unmarried women.

We may also argue that there are a number of allusions to the incident of Bilhah and Reuven and the Genesis text in which it is set: the unusual

Exum, Fragmented Women, 179.

98 Bal, Death and Dissymmetry, 195, quoting Elaine Scarry, The Body in Pain: The Making and Unmaking of the World (New York: Oxford University Press, 1985), 53. Interestingly, it is this violation of public-private spheres that caught the attention of a later sage, as recorded in the following statement in bGitt. 6b:

\section{אמר רב חסדא לעולם אל יטיל אדם אימה יתירה בתוך ביתו שהרי פילגש בגבעה הטיל עליה בעלה אימה יתירה והפילה כמה רבבות מישראל בתוך ישיתו שירות}

Rav Hisda said: A man should not throw excessive terror into his household, given [the story of] the pilegesh in Gibeah - her husband terrorized her excessively, and it [or she] caused the downfall of tens of thousands of Israelites.

I discuss this opinion further in "A Re-embracement of Judges 19: Challenging Public-Private Boundaries."

This association between thresholds and ambiguous status is powerfully suggested Margaret Atwood, The Handmaid's Tale (Toronto: McClelland \& Stewart, 1985), a novel that depicts a dystopia in which young women are forced to bear children to a male elite whose wives are barren. The "handmaid" of the title describes her entry into an elite household in this way (ibid. 13): "On our first days we are permitted front doors, but after that we're supposed to use the back. Things haven't settled down, it's too soon, everyone is unsure about our exact status. After a while, it will be either all front doors or all back.” 
(non-)reactions of both Jacob and the Levite to the violence committed against the women; the emphasis on the twelve sons of Jacob in Genesis and the twelve dismembered body parts in Judges; and the juxtaposition of Judah (Rachel dies near Bethlehem; the pilegesh originates in Bethlehem), Joseph, the first of Rachel's sons (the Levite and his host are Ephraimites) and Benjamin, the second of Rachel's sons (the murderers are Benjaminites). This pattern of intra-biblical parallels, like the others noted by scholars, suggests the deliberate use of a motif.

\subsection{CONCLUSION}

We may conclude that the pilegesh, the "consort," is a convenient figure in biblical aetiologies: illicit sexual behaviour with the pilegesh may lead to disaster, yet the term is sufficiently vague to allow the patriarchs to associate with them with no diminution of patriarchal stature. The use of the term pilegesh in Gen. 35:22 may thus have been an intentional insertion - to suggest the danger associated with the pilegesh (in this case, Reuven's loss of firstborn status), but also to "soften" the suggestion that Reuven committed incest with his father's wife (a concern quite evident in postbiblical sources). Similarly, Qeturah's description as a pilegesh in Chronicles, though she is called an ishab in Genesis, may have been intended to "soften" Abraham's relationship with her and thus enhance Sarah's preeminence as Abraham's only "wife." Our results also indicate that the biblical pilegesh was also not conclusively associated with slavery. 
